\title{
A memória de Miramar: decompondo e recompondo a memória ficcional
}

\section{Natália Ubirajara Silva*}

Resumo: o presente artigo reflete sobre as Memórias Sentimentais de João Miramar, de Oswald de Andrade, procurando compreender em que medida essa obra se aproxima do paradigma da memória ficcional (as Memórias Póstumas de Brás Cubas, de Machado de Assis) para recriá-lo e subvertê-lo.

Palavras-chave: Oswald de Andrade; memória; paródia; fragmentação.

\begin{abstract}
Memórias Sentimentais de João Miramar, by Oswald de Andrade, trying to find in which way this piece relates to the paradigm of fictional memories (Memórias Póstumas de Brás Cubas, by Machado de Assis) in order to recreate and subvert it.
\end{abstract}

Keywords: Oswald de Andrade; memory; parody; fragmentation.

\section{Meus olhos vão buscando lembranças \\ Como gravatas achadas \\ Memórias Sentimentais de João Miramar, Oswald de Andrade}

\section{A escrita da memória}

No diálogo Fedro, Platão apresenta, pelas palavras de Sócrates, uma passagem sobre a invenção da escrita. Segundo esse episódio, a escrita teria sido criada pelo deus egípcio Toth. Este, ao mostrar seu invento a Amon, afirma que a arte da escrita "tornará os egípcios mais sábios e lhes fortalecerá a memória"; Amon, porém, responde: "Tal cousa tornará os homens esquecidos, pois deixarão de cultivar a memória [...] tu não inventaste um auxiliar para a memória, mas apenas para a recordação" (PLATÃO, 1962, p.256). Portanto, a escrita é apresentada no Fedro não como um facilitador, mas como uma perda da capacidade de evocar as experiências do passado. Platão vivenciava um momento de transição, em que a oralidade cedia a primazia à palavra escrita, e por isso essa preocupação se fazia procedente. Porém, se analisarmos a trajetória da escrita do século IV a. C. até nossos dias, veremos que a invenção de Toth não resultou em uma perda de memória, e sim em novos meios de resgatá-la.

\footnotetext{
"Natália Ubirajara Silva é mestranda em Literatura Brasileira, Portuguesa e Luso-africana pela Universidade Federal do Rio Grande do Sul (UFRGS) e co-editora do periódico Cadernos do IL (publicação do Instituto de Letras da UFRGS). Este trabalho foi realizado com o apoio do CNPq-Brasil.
} 
A expressão da memória se dá necessariamente pela linguagem, tanto oral como escrita. Embora apresentem trajetórias praticamente simultâneas, esses dois tipos de registro são autônomos, com identidades, suportes e funcionamento próprios. Nesse sentido, Benjamin aponta para uma cesura entre o que é da conta do universo escrito (do "romance") e oral (da "narrativa"): "Quando no decorrer dos séculos o romance começou a emergir do seio da epopéia, ficou evidente que nele a musa épica - a reminiscência - aparecia sob outra forma que na narrativa" (BENJAMIN, 1993, p.211) ${ }^{1}$. Surge, assim, o questionamento: como a memória, aliada à imaginação, é recuperada no texto escrito? Como ela é transformada, pelo autor, em narrativa?

Todo texto lida com memória. A ficcionalização é formada em boa parte pela recriação de lembranças evocadas; a mímese é uma "atividade complexa de contaminação do real e do imaginário [...] o que caracteriza a ficção (o trabalho da mímesis) é a relação triádica entre o real, o ficcional e o imaginário" (HELENA, 1985, p.50-51). Podemos dizer que é a memória que funda a narrativa, pois todo autor, ao criar, acaba inevitavelmente se utilizando de sua "bagagem" pessoal de vivências e aprendizagens. Há obras literárias que trazem explicitamente a evocação das lembranças, enquadradas pela crítica literária como pertencentes ao gênero memorialístico; servem de exemplo as Confissões de Santo Agostinho, as Confissões de Rousseau e, na literatura brasileira, as Memórias de Visconde de Taunay. Os textos de caráter memorialístico apresentam algumas características recorrentes, como a narração em primeira pessoa, a importância da cronologia, episódios marcantes, panorama histórico da época e balanço da vida.

Entretanto, existe ainda outro modo de escrever a memória explicitamente: ficcionalizá-la, ou seja, representar na ficção os processos da memória, como fez Proust em seu Em busca do tempo perdido (1913-1927). Assim, os traços do romance memorialístico são mantidos, mas para narrar a trajetória de uma personagem fictícia. Na literatura brasileira, o primeiro romance que apresenta explicitamente o projeto de ficcionalizar a memória data de 1881: Memórias Póstumas de Brás Cubas, de Machado de Assis. O memorialismo fictício brasileiro começou, com esse romance, a dar seus primeiros passos.

\section{Memórias póstumas de Brás Cubas: o paradigma da memória ficcional brasileira}

\footnotetext{
${ }^{1}$ Uma tradução mais elucidativa dessa citação é a que segue: "Quando, no decurso dos séculos, o romance começa a emergir do ventre da epopéia, o elemento épico que deriva da musa - a saber, a memória - manifestase de modo muito diferente daquele que se apresenta na narrativa” (Trad. Profa. Regina Zilberman).
} 
Embora seja, atualmente, o padrão do texto memorialista "tradicional" de nossa literatura, o romance Memórias Póstumas de Brás Cubas não se trata de um texto “ortodoxo”, fiel aos paradigmas estilísticos da literatura que se fazia no Brasil em meados do século XIX. Apesar de se valerem de algumas características próprias do gênero memorialístico, elas subvertem a estrutura. Por tratar-se de memória ficcionalizada, o romance de Machado faz com que algumas transgressões tornem-se possíveis: um defunto autor, detentor do poder de narrar até mesmo o fim de sua trajetória; fragmentação (as Memórias são escritas "sem a rigidez do método", cf. ASSIS, 1997, p.34); ruptura com a cronologia, resultando numa narrativa a-linear (Brás Cubas começa suas Memórias narrando seu funeral). A ficcionalização dos processos da memória permite até mesmo que seja possível ao defunto autor narrar um estado de delírio, como vemos no capítulo VII (“O delírio”).

Em meio a esses novos elementos formais, porém, dois traços característicos do romance de memórias permanecem: o panorama sócio-histórico e o balanço da vida, traçados com a "pena da galhofa e a tinta da melancolia" (cf. ASSIS, 1997, p.13). Quanto ao panorama sócio-histórico, percebe-se nas Memórias Póstumas uma ironia mordaz dirigida aos códigos da elite brasileira. Brás Cubas desvela o amor da nomeada, força motriz por gerações em sua família, e o reinado das aparências nas relações interpessoais: "os homens valem por diferentes modos [...] o mais seguro de todos é valer pela opinião dos outros homens" (ASSIS, 1997, p.79). Morto, o narrador tem total liberdade para trazer à luz os códigos vigentes em sua sociedade: "agora, porém, que estou cá do outro lado da vida, posso confessar tudo" (ASSIS, 1997, p.17).

Quanto ao segundo aspecto - o balanço da trajetória vivenciada - , percebemos que os acontecimentos selecionados por Brás Cubas são relevantes para que o leitor possa reconstruir seu caráter. Tudo o que serve para julgar sua existência é considerado: episódios aparentemente comezinhos (os conselhos paternos, o arrependimento de Brás ao dar um cruzado de prata a um almocreve que lhe fizera uma boa ação, a vingança do menino Brás contra o glosador Dr. Vilaça, dentre outros), casos amorosos (Marcela, Eugênia, Virgília), a amizade com Quincas Borba, o envolvimento na política, etc. Brás Cubas propõe-se a, do túmulo, escrever memórias "nas quais só entra a substância da vida" (ASSIS, 1997, p.67). Nelas, portanto, todos os episódios narrados são importantes, por mais mesquinhos que possam parecer, pois compõem um quadro do caráter do defunto autor. Após a narração desses eventos, segue-se uma avaliação de tudo o que foi apresentado: "Não tive filhos, não transmiti a nenhuma criatura o legado da nossa miséria” (ASSIS, 1997, p.241). 
Vemos, assim, que o paradigma de memória ficcional lançado por Machado de Assis é o da lucidez (olhar crítico e irônico sobre a sociedade e também a cultura da época) e da transgressão formal.

\section{Memórias sentimentais de João Miramar: a subversão do paradigma}

O modelo de memória ficcionalizada lançado por Machado de Assis pode ser resgatado nas Memórias Sentimentais de João Miramar (1924), de Oswald de Andrade. Parte da crítica literária tem se concentrado, desde o auge do Modernismo, em apresentar a faceta "demolidora" dos autores da década de 20, em detrimento do valor estético de suas obras. Segundo Martins, por exemplo, Oswald de Andrade representa "o lado frívolo do Modernismo", pois vivia o "escândalo pelo prazer de escandalizar" (MARTINS, 1973, p.241). Martins chega ainda a dizer que, pelo fato de Oswald guardar seus escritos durante anos na gaveta, suas obras eram avançadas quando elaboradas, mas atrasadas quando da publicação (cf. MARTINS, 1973, p.245). Essa afirmação, no entanto, tem se revelado improcedente. Graças ao resgate operado principalmente pelos Irmãos Campos, a partir da década de 1970, os textos oswaldianos começaram a ser analisados sob outro prisma, considerando seu valor literário; essa análise mais acurada e despida de preconceitos permitiu que a qualidade, a complexidade e a atualidade da escrita de Oswald fossem percebidas.

Apesar dessa nova visada crítica, ainda são freqüentes as análises que levam em conta apenas a influência das vanguardas européias na produção oswaldiana. Limitando a visão a essa característica, aspectos até mesmo mais interessantes são relegados a segundo plano. Um deles - e que aqui nos interessa particularmente - é o forte diálogo de Oswald com a tradição literária brasileira. Cremos que ele dá continuidade ao caminho aberto por Machado de Assis. As Memórias Sentimentais de João Miramar são uma decomposição e recomposição do paradigma lançado nas Memórias Póstumas de Brás Cubas. Seguindo a lição de Machado (que transgrediu o estilo romanesco vigente) e atualizando-a para o contexto brasileiro das primeiras décadas do século XX, Oswald apresenta ao público-leitor um texto de memória ficcional totalmente subversivo - como, talvez, o de Machado o fora em 1881. Nas Memórias Sentimentais, encontramos não apenas a construção ficcional dos processos da memória, mas também uma paródia a essa construção, na qual o autor se apropria de elementos próprios do gênero de memórias a fim de subvertê-los.

Veremos, a seguir, três eixos norteadores do romance de Miramar: a "memória da banalidade", a "memória como paródia" e a "memória em estilhaços". 


\title{
3.1 A memória da banalidade
}

O narrador-personagem João Miramar apresenta um relato fragmentário de sua trajetória, dividido em 163 "episódios-fragmento" (cf. CAMPOS, 1990, p. 12). O título dá a entender ao leitor que a narrativa apresentará, como é de praxe nos textos memorialísticos, os fatos mais relevantes e marcantes da vivência de Miramar; trata-se, porém, de uma pista falsa. O leitor das Memórias se depara com um romance de seqüenciação difusa e sem acontecimentos proeminentes. Miramar desestabiliza seu leitor, e "o 'prazer' que o leitor de memórias espera (isto é: o de acompanhar os acontecimentos da vida de seu personagem numa ordem clara e plausível, ainda que sob o flashback) é frustrado" (HELENA, 1985, p.92). No entanto, apesar dessa dispersão narrativa, há uma certa interdependência entre os fragmentos. Vale lembrar o que Helena aponta:

\begin{abstract}
Ainda que Memórias Sentimentais de João Miramar e Serafim Ponte Grande não sejam, convencionalmente, livros de memórias, Oswald apresenta-os como uma memória ficcional em que os personagens estão a remexer nos guardados de suas experiências de vida. E é esta retomada dos guardados que vai dar aos seus livros mais fragmentários uma seqüenciação. (HELENA, 1985, p.92)
\end{abstract}

Assim, por mais fragmentárias que sejam as lembranças de Miramar, há um fio narrativo, uma linearidade, ainda que frágil. Procurando garantir uma melhor compreensão das Memórias, Kenneth Jackson apresenta uma divisão do romance oswaldiano em três partes, agrupadas sob o tema da viagem (antes, durante e depois): “do fragmento 1 ao 27, temse a tematização da vida de Miramar, sua família, seus amigos. Do 28 ao 55, as viagens pela Europa. Do 56 ao 163, o mundo social, profissional, cartas da família e dos amigos" (HELENA, 1985, p.88). Essa seqüenciação sistemática é válida para perceber a interdependência entre os fragmentos, porém é importante ter clareza de que a viagem à Europa não é o centro em torno do qual gravitam os episódios de Miramar.

Sabemos que o tema da viagem é uma constante na obra oswaldiana; há, inclusive, diversos paralelos entre as viagens de Oswald e a de João Miramar (Oswald conhece Landa, Miramar conhece Rolah; ambos hospedam-se no mesmo albergue parisiense; ficam órfãos de mãe na viagem de retorno). O próprio Oswald reitera, em suas memórias (Um homem sem profissão: sob as ordens de mamãe), que seu nome é Miramar (cf. ANDRADE, 1990b, p.112), deixando claro que em sua criação há "o aproveitamento, submetido a uma elaboração ficcional, fragmentadora, de muito de sua experiência vivida" (SCHWARTZ, 1983, p.81). Entretanto, a despeito de todas essas ligações, não consideramos que a viagem de Miramar à 
Europa tenha, nas Memórias, a mesma relevância que as viagens reais de Oswald tiveram em sua criação. Encaramos a totalidade do périplo miramarino como um panorama da elite brasileira dos inícios do século XX - e essa é uma das características do texto de memória ficcional que Oswald mantém. No romance, a ida à Europa é apenas mais uma das empreitadas fúteis entabuladas pelo narrador e também por seus coetâneos. Vale lembrar que muitas outras personagens também perambularam pelo Velho Mundo, como a tia Gabriela e suas filhas, o Conde José Chelinini, o primo Pantico, o artista Dalbert (com subsídio do governo), o Dr. Pilatos da Glória, dentre outros. O foco a que devemos ajustar nossa lente de leitores, mais do que a viagem à Europa, é a elite paulista, com seu verniz de cultura e valores frívolos. As Memórias são "um grande ideograma crítico-satírico do estado social e mental de São Paulo nas primeiras décadas do século" (CAMPOS, 1990, p.30).

Nas Memórias miramarinas, “a burguesia endinheirada roda pelo mundo o seu vazio, as suas convenções, numa esterilidade apavorante" (CANDIDO, 1992, p.25). A vida de Miramar é efetivamente estéril, um périplo sem conseqüências: "matrimônio - amante desquite - vidinha literária - peripécias financeiras" (CAMPOS, 1990, p.20). Enquanto as aparentes banalidades que Brás Cubas narrava tornavam-se totalmente justificadas após alguns capítulos, as vivências de Miramar são vazias, compondo o seu caráter e também o de sua sociedade (a elite paulista, desde os cafeeiros até os imigrantes emergentes). Como assinala Campos, "o Miramar [...] é bem um misto de diário sentimental e de jornal dos faits divers duma sociedade provinciana e ociosa, cujo barômetro era a alta do café ou a sua crise" (CAMPOS, 1990, p.19). No fragmento em que Miramar narra seu casamento com a prima Célia ("62. Comprometimento”), em vez de um relato sentimental, é apresentado ao leitor um comentário concernente aos trâmites financeiros: "o dia continuou tendo havido entre nós apenas uma separação precavida de bens" (ANDRADE, 1990a, p.64). Inserido na lógica burguesa, Miramar considera essa informação necessária ao leitor de suas Memórias. Em outros episódios evidencia-se que até mesmo as camadas sociais desprivilegiadas se orientam pela ótica do capitalismo incipiente daquela São Paulo. Exemplo disso é o motorista da família: "Lá fora, o Serapião etíope restituído a funções de uniforme branco, declarava ser perciso cavar uma baita limosina Rosróis para ser família cotuba” (ANDRADE, 1990a, p.86).

Dois episódios-fragmento "param" a seqüência narrativa para kodakar (cf. CANDIDO, 1992, p.26) o panorama paulista. São eles: “105. Corretorópolis" e "122. Vanity fair”. O primeiro corresponde a uma descrição das movimentações econômicas de São Paulo, a "Corretorópolis" na qual surgiam os primeiros milionários que, "risonhos modestos atravessavam sob carícias de olhares as ruas bolsentas emitindo cheques visados contra 
inquebráveis bancos" (ANDRADE, 1990a, p.82). Por sua vez, o fragmento 122 refere-se ao jogo social paulista, verdadeira "fogueira das vaidades" em que os interesses, a inveja, a maledicência e o esnobismo imperam: "D. Pequitiboca [...], enxovalando filhas com dúzias de dessous avistadores de alianças fortunais. Nhôs levantavam palácios confeiteiros questionando que quadros ou fossem assinados por figurões do Larousse ou pelo Barbabassi” (ANDRADE, 1990a, p.88).

Sendo assim, as Memórias de Miramar, a exemplo das de Brás Cubas, valem-se da memória como depoimento crítico de sua época. Os narradores de Machado e Oswald fazem parte da elite e, embora pertençam a períodos históricos diferentes, desvelam ao leitor a esterilidade de suas vivências. Além disso, ambos exibem um certo mau-caráter, denunciando o império da malandragem e da futilidade nas camadas que regem a nossa sociedade.

\subsection{A memória como paródia}

Ao lermos as Memórias Sentimentais, uma questão se impõe: como um destruidor do passado, como Oswald de Andrade, propõe-se a falar sobre memória? Essa pergunta surge de um erro de leitura. Se analisarmos o romance - e também outros textos oswaldianos entenderemos que o autor não é contrário ao passado e à tradição, mas ao academicismo. Sua "fúria demolidora" é direcionada à cristalização dos valores literários, pois ela impede que novos elementos sejam agregados à tradição. Uma das epígrafes das Memórias Sentimentais já indica que não há rejeição ao passado, ao ser extraída de um tratado anônimo do século XVII, Arte de furtar. Diz ela: "E se achar que falo escuro não mo tache, porque o tempo anda carregado; acenda uma candeia no entendimento..." (ANDRADE, 1990a, p.41). Metalingüisticamente, o próprio texto alerta seu leitor quanto à sua complexidade. Não se trata apenas de uma instigação, mas também uma provocação: aqueles que porventura vierem a considerar o texto oswaldiano como escuro, talvez não tenham acendido as candeias no entendimento... Como lembra Schwartz (1983, p.164), o tema da epígrafe é retomado no prefácio, escrito pela personagem Machado Penumbra: "Pena é que os espíritos curtos e provincianos se vejam embaraçados no decifrar do estilo em que está escrito tão atilado quão mordaz ensaio satírico" (ANDRADE, 1990a, p.44).

Portanto, não temos nas Memórias uma destruição do passado, mas uma tentativa de renovação. O contexto cultural da elaboração do romance oswaldiano era de estagnação: "Os valores estáveis da mais atrasada literatura do mundo impediam qualquer renovação. Bilac e Coelho Neto, Coelho Neto e Bilac" (ANDRADE, 1990b, p.84). A crítica a essa realidade se 
dá por meio da paródia ao discurso institucionalizado, à linguagem acadêmica (cf. SCHWARTZ, 1983, p.202). A paródia oswaldiana é uma crítica ao "mal da eloqüência balofa e roçagante" (PRADO apud CAMPOS, 1990, p.11), cujos representantes maiores eram, naquele contexto, os parnasianos, bacharéis, membros de grêmios e academias.

Uma das paródias ao discurso institucionalizado dirige-se contra os "medalhões" do âmbito cultural. Aliás, a sátira aos figurões da intelectualidade é um paralelo possível entre as Memórias de Miramar e as de Brás Cubas. Assim como Machado satiriza os intelectuais contemporâneos (na figura do Dr. Vilaça, glosador que afirmava ser parceiro de botequim do poeta português Bocage, e no próprio Brás, bacharel que sai da Universidade com os mesmos parcos conhecimentos de quando nela havia ingressado), Oswald arremete contra aqueles que prescreviam os padrões e valores da "alta literatura". Miramar, por exemplo, ingressa no Instituto Histórico apenas para não destoar do resto dos homens de sociedade:

Célia achava que eu devia ter uma vocação nobilitante. Eu não tinha nenhuma. Pensava vagamente em entrar para um club de box depois de ter sido minha compleição elogiada por um entraîner da Rua do Catete [...] Eu pendia mais para bilhares centrais que para pesquisas científicas. Era dono de casa com safras longínquas livros quadros criados e a senhora grávida. Mas aquela noite fui introduzido no enceramento abobadal e branco do Instituto (ANDRADE, 1990a, p.66-67)

Petulante, pomposo e grandiloqüente, o discurso dos membros do Instituto torna-se ridículo no contexto da modernidade. Serve de exemplo o elogio que o Dr. Pilatos da Glória faz a Miramar: "Seu marido, minha senhora, parece Telêmaco segundo o Fénelon na tradução portuguesa em quem era de admirar tanta facúndia em tão verdes anos" (ANDRADE, 1990a, p.68). Vê-se que a especialidade desses intelectuais é expor a todos a sua erudição, sem perceber que ela é, na realidade, superficial e retrógrada. A linguagem de Pilatos, sempre com seus "ohs e ahs", é uma paródia que se aplica a toda a intelectualidade estagnada daquele período:

Eu já passei com um almoço por semana e cheguei à posição que cheguei. Sou um autodidata! E já fui citado pelo padre Berlangete da Universidade Católica de Beirute. Escrevi a biografia do patriarca Basílio 8 que foi torrado numa igreja por causa de Orígenes. Irei à Ravena estudar de perto o $5^{\circ}$ século. As academias orientalistas abrir-me-ão as portas, oh! ah! (ANDRADE, 1990a, p.75)

Há ainda outra sátira aos intelectuais no último fragmento. O Dr. Pilatos, após ler o texto de Miramar, afirma que ele lembrou-lhe "Virgílio, apenas um pouco mais nervoso no estilo" (ANDRADE, 1990a, p.107). Ao tentar encaixar a obra de Miramar nos velhos códigos, nos padrões já existentes, Pilatos demonstra não ter compreendido a obra; sequer percebeu 
que nela havia uma crítica dirigida a si mesmo e a seus iguais. Muitas vezes, os intelectuais são aqueles que lêem as obras modernas e não acendem a "candeia no entendimento".

A paródia a Machado de Assis é constante nas Memórias Sentimentais. Ela pode ser percebida no grande e eloqüente orador Machado Penumbra, que além de personagem é autor do prefácio. Penumbra não é sátira e paródia dirigida somente ao autor das Memórias Póstumas: as principais "vítimas" são os cultores da linguagem acadêmica. Nesse sentido, não podemos esquecer que Machado de Assis foi o primeiro presidente da Academia Brasileira de Letras, e é provável que o ataque oswaldiano seja dirigido mais a seus sucessores (os que "congelaram" os valores literários) do que a Machado propriamente. Também podemos entrever a figura de Machado de Assis na personagem Minão da Silva, agregado da fazenda de Miramar e "jovem orgulho mulatal" do Grêmio Bandeirantes (ANDRADE, 1990a, p.76). Semi-analfabeto pernóstico, Minão não domina a norma culta, mas mostra ter o domínio da linguagem acadêmica, reproduzindo-a em todos seus clichês e cacoetes. Miramar, inclusive, chega a chamar Minão de "meu agregado lombardo" (ANDRADE, 1990a, p.76), pois o mulato reproduz fielmente o estilo dos eloqüentes e enfadonhos oradores parnasianos. $\mathrm{O}$ linguajar empolado de Minão chega a beirar a incoerência:

[...] estudarei para ser a Luz de minha família. Representar talento com meu falecido avô Capitão Benedito da Força Pública, não estudando agora, quando mais o tempo passa e a Velhice chega conduz a Tristeza, porque este mundo é um passatempo que nós temos essa é a Verdade! Só temos que tratar do Futuro neste mundo não valhe nada a Beleza as Festas as Inlusão do mundo só o talento com o grande Rio Branco o Ouro Preto, O Padre feijó, José Bonifácio, Rui Barbosa e outros que nem se sabe (ANDRADE, 1990a, p.91)

Além do velho clichê parnasiano do uso de maiúsculas, que Minão imita sem critério ("Velhice", "Inlusão", "Festas"), o louvor a Rui Barbosa ilustra muito bem quais eram os padrões ditados na literatura, estacionários desde meados do século XIX. Assim como o motorista da família reproduz a ideologia econômica dominante (ter "Rosróis" para a família ser "cotuba"), o agregado da fazenda repete a linguagem acadêmica. Minão está exatamente no mesmo nível que os renomados Mandarim Pedroso, Pilatos da Glória, poeta Fíleas, etc. As Memórias são, como analisa Mário de Andrade, uma "sátira extraordinariamente feliz de certa formação brasileira em que o pernóstico do cafuzo se junta a um doirado de cultura quase indigente" (ANDRADE apud FONSECA, 1987, p.50-51), todos unidos em uma comunidade de arrogância, imbecilidade e mediocridade. As Memórias Sentimentais são, portanto, uma "decomposição irônico-paródica do arcabouço intelectual conservador da sociedade brasileira" (HELENA, 1985, p.138). 
Enquanto a intelectualidade brasileira perdia-se em elucubrações vãs, a nova geração Oswald e os outros modernistas - percebia a necessidade de introduzir no país uma nova forma de arte, sintonizada com o momento histórico e com raízes verdadeiramente nacionais:

O erro dos nossos censores é o erro de todos os envelhecidos: estão fora da psicologia do telégrafo sem fios, do aeroplano, da estrada empedrada de automóveis e o seu armário de musas move fantasmas longínquos e torvos num João Minhoca decaído em velhos plágios façanhudos (ANDRADE apud CAMPOS, 1990, p.29)

Nessa dura crítica à arte engessada e cristalizada, presa aos clássicos de maneira ingênua e acrítica, Oswald propõe uma abertura da intelectualidade às transformações da vida moderna. Quanto a isso, é importante considerar o que diz o prefácio de Machado Penumbra, o qual, apesar do inevitável empolamento, demonstra lucidez e relativa abertura ao novo. "Joco-sério" (cf. CAMPOS, 1990, p.10), o prefácio pode ser lido sob duas perspectivas: paródia, no nível da linguagem; manifesto oswaldiano, no nível do conteúdo. Machado Penumbra afirma serem as Memórias fruto de "uma época insofismável de transição" (ANDRADE, 1990a, p.43): "Como os tanks, os aviões de bombardeio sobre as cidades encolhidas de pavor, os gases asfixiantes e as terríveis minas, o seu estilo e a sua personalidade nasceram das clarinadas caóticas da guerra" (ANDRADE, 1990a, p.43). O texto de Miramar tem origem na vivência da modernidade, seu estilo é conseqüência da experiência da guerra: a velocidade, o desenvolvimento tecnológico, o choque. Penumbra reconhece nas inovações miramarinas algumas qualidades, como a língua modernista (mescla do português com as línguas imigradas), o estilo telegráfico e a metáfora lancinante. Para o orador, Miramar traçou um "quadro vivo de nossa máquina social” (ANDRADE, 1990a, p.44). Nesse prefácio, Oswald de Andrade "contribui com [...] dados teóricos sobre os elementos que compõem sua obra", mostrando ter relativa "consciência de seu papel renovador" (SCHWARTZ, 1983, p.165). As Memórias são um dos esforços de Oswald para tirar a cultura brasileira de um estado estacionário, buscando alcançar a sua modernização.

Uma das recomposições do paradigma da memória ficcional que chama atenção nas Memórias é seu final: Miramar interrompe a narrativa abruptamente. Ele opta por silenciar, tempos após o falecimento da ex-mulher, seguindo o conselho de Mandarim Pedroso, para quem "os viúvos devem ser circunspectos" (ANDRADE, 1990a, p.107). Miramar, membro da elite fútil retratada em seu texto, continua ligado aos códigos e valores de sua classe. Ao contrário de Oswald, Miramar se contenta com os elogios medíocres dos seus colegas de Instituto. Alguns episódios antes, o narrador falava consigo mesmo: "És o elo duma cadeia infinita/ abraça o Dr. Mandarim/ E soma ele ao azul desta manhã/ Louçã”" (ANDRADE, 
1990a, p.103), ou seja, já nos últimos fragmentos de sua narrativa, Miramar cogita tomar para si os valores do Dr. Mandarim. Tomamos o último episódio-fragmento, "163. Entrevista entrevista" um diálogo do narrador consigo mesmo, no qual pesa suas atitudes e as conseqüências que elas teriam:

- O Dr. Mandarim, com perdão da palavra, é uma besta!

- Engano seu. O Dr. Mandarim é baedecker de virtudes. Adoto-o.

- A crítica vai acusá-lo e a posteridade clamar porque não continuou tão rico monumento da língua e da vida brasílicas no começo esportivo do século 20.

- Já possuo o melhor penhor da crítica. Li as Memórias, antes do embarque, ao Dr. Pilatos (ANDRADE, 1990a, p.107)

A escolha foi feita: Miramar decide se submeter aos códigos ditados pelos membros do Instituto. Para isso, é necessário calar as suas Memórias, renovadoras da "língua e da vida brasílicas” (ANDRADE, 1990a, p.107). No momento em que já fez, como diz Machado Penumbra, "sua entrada de homem moderno na espinhosa carreira das letras" (ANDRADE, 1990a, p.43), Miramar fica satisfeito. Para ele, a aclamação dos medalhões da cultura era mais importante do que revolucionar a prosa brasileira moderna. Nesse sentido, ele é uma espécie de par oposto de seu criador, Oswald, que preferiu desprender-se dos valores culturais da elite, a que pertencia, e propôs-se a criar uma arte renovada.

É em virtude desse esforço de renovação que o narrador oswaldiano subverte o paradigma da memória ficcional. Decompor e recompor os esquemas narrativos vigentes não é um mero exercício estilístico e/ou reprodução de técnicas européias. Para Campos, a prosa renovada de Oswald é uma "adequação pessoal e reelaboração" (CAMPOS, 1990, p.33) dos procedimentos vanguardistas, visando a representar e questionar o contexto social brasileiro. As Memórias Sentimentais superam “os possíveis 'cacoetes' de escola, aponta[m] rumos insuspeitados para nossa literatura" (CAMPOS, 1990, p.33). Ao subverter os modelos estagnados do cânone, Oswald abre caminho para o futuro da criação literária brasileira.

\subsection{A memória em estilhaços}

A fim de registrar a "memória da banalidade" e a memória enquanto paródia à estagnação e mediocridade, Oswald de Andrade vale-se de processos diferenciados. Um deles, já mencionado, é a divisão da obra em fragmentos. Eles são, como aponta Helena,

'pílulas' de memórias [...] Miríades de fragmentos, flashes descontínuos de cenas que não se comprometem com uma causalidade cronológica de princípio/meio/fim são inseridos, entrecortando o tênue fio da linearidade [...] Não falta a ambos uma tênue sequiência de início/meio/fim de quem retoma lembranças e tenta organizá-las. Mas esta atitude é diluída, o encadeamento dessa lógica linear é constantemente golpeado pela interpenetração de 
fragmentos de lembranças não imediata nem facilmente conectáveis pelo leitor (HELENA, 1985, p.92-93)

Como vimos anteriormente, a narrativa miramarina é dividida em 163 episódiosfragmento, ou ainda “capítulos-sensações” (cf. BOSI, 2004, p.359). Esta última denominação, aliás, explica o título da obra: as Memórias são sentimentais não por tratarem de fatos da vida amorosa de um burguês (embora esse elemento também exista), mas por serem compostas pelo registro da memória das sensações vividas. Nos primeiros fragmentos, que retratam a infância, a percepção do narrador é a de uma criança: "No silêncio tique-taque da sala de jantar informei mamãe que não havia Deus porque Deus era a natureza. Nunca mais vi o Seu Carvalho que foi para o Inferno" (ANDRADE, 1990a, p.47). Nesse episódio, a memória de Miramar é registrada do modo como é evocada, sem questionamentos, juízos críticos ou explicações "adultas". É apenas o título, "Fraque do ateu", que direciona a leitura, elucidando que Seu Carvalho, professor, era ateu e ensinara idéias não-católicas ao pequeno Miramar.

Nossa memória é associativa; quando a evocamos, as lembranças não acorrem linearmente, mas ligadas a sentimentos e outras recordações, ou seja, estilhaçadas:

\section{GARE DO INFINITO}

Papai estava doente na cama e vinha um carro e um homem e o carro ficava esperando no jardim.

Levaram-me para uma casa velha que fazia doces e nos mudamos para a sala do quintal onde tinha uma figueira na janela.

No desabar do jantar noturno a voz toda preta de mamãe ia me buscar para a reza do Anjo que carregou meu pai (ANDRADE, 1990a, p.46)

Nesse fragmento, Miramar narra a morte de seu pai, mas com a sua percepção de menino. O homem que chegava no carro era o médico; após um corte brusco, é narrada a mudança de casa e o período de luto, em que Miramar e sua mãe rezavam pela alma do pai. Assim como no episódio do professor ateu, não há reflexão posterior do adulto: os fatos são narrados do mesmo modo em que foram "gravados" na memória de João Miramar. Quanto a esse aspecto, percebe-se que os fragmentos relativos à idade madura são de mais fácil compreensão, pois neles o narrador já representa a organização mental do raciocínio adulto:

\section{A DENÚNCIA}

Entrei em Higienópolis para jantar e sobre a mesa um telegrama azul exigia minha imediata presença nos Bambus. Célia sabia tudo laconicamente.

Rolah pediu-me que telefonasse trin-trin contando o que havia.

$\mathrm{O}$ trem a manhã e a chuva eram um corador de roupa branca. E parti na direção de trolly da serra fazendeira num cheiro de curral e de selva (ANDRADE, 1990a, p.94)

A lembrança de Miramar, como vemos acima, não se restringe aos acontecimentos propriamente ditos: a eles são associadas as sensações experimentadas naquele determinado momento, como o toque do telefone, a chuva, o cheiro das matas na viagem rumo ao interior 
do Estado. A compreensão, diferentemente dos fragmentos referentes à infância, é mais acessível.

Nos episódios-fragmento, Oswald vale-se de dois processos principais: a montagem e a construção metonímica. Complementares, essas duas técnicas têm sua origem atribuída, pelos críticos, ao cinema e ao cubismo:

[...] a técnica de montagem - que é sobretudo uma técnica de criação de contexto através da manipulação de relações de contigüidade [...], implicando elipses (suspensões ou cortes bruscos), traduz freqüentemente a atitude metonímica com que o pintor cubista [...] reordena o mundo exterior no correal estético que é o quadro, selecionando este ou aquele detalhe (CAMPOS, 1967, p.89)

É da seleção de detalhes que Oswald se vale para compor as Memórias. A atitude metonímica, na qual se toma a parte pelo todo, como num close up cinematográfico, é própria da memória: nossa memória sempre é afetada por uma forte carga emocional (sentimentos, impressões, sensações físicas, etc.). É por meio desse processo que o leitor é apresentado a um panorama do bairro londrino do Soho, tal como se assistisse a uma filmagem: "Picadilly fazia fluxo e refluxo de chapéus altos e corredores levando ingleses duros para música e talheres de portas móveis e portas imóveis [...] Bicicletas levantavam coxas velhas de girls para napolitanos vindos da Austrália" (ANDRADE, 1990a, p.59). Miramar "filma" o Soho, percorrendo-o com seu olhar, narrando apenas aquilo que é focado em sua "lente": os chapéus altos destacando-se na multidão, as coxas das girls nas bicicletas, música e talheres nos restaurantes londrinos. Por meio da montagem e da metonímia, Miramar busca literalmente lembranças com os olhos (cf. ANDRADE, 1990a, p.61).

A linguagem empregada para registrar a memória miramarina também se vale da metonímia: "os processos de montagem provocam na economia narrativa um sistema retórico em que metáforas e metonímias aceleram as seqüências narrativas”, num esforço de “expressar o máximo com o mínimo” (SCHWARTZ, 1983, p.68). Essa economia narrativa é um dos responsáveis pela dificuldade de leitura das Memórias, num primeiro contato: "José Chelinini [...] filho de cereais varejos" (ANDRADE, 1990a, p.49), assinalando a origem imigrante do colega de escola e futuro conde; "Depois de cima, pensão de artistas, caíam pingos profundos de Chopin na comida" (ANDRADE, 1990a, p.52), dizendo que algum artista vizinho tocava Chopin, e sua música ressoava em todos os andares da pensão; "gondolamos graciosamente na Ponte de Rialto e suspiramos na outra" (ANDRADE, 1990a, p.58), na viagem a Veneza. Esses são apenas alguns exemplos, que provam ser infundadas as críticas que diminuem a qualidade técnica de Oswald como escritor. Quanto a isso, vale lembrar o que diz Calvino: "Para se alcançar a imprecisão desejada, é necessário a atenção 
extremamente precisa e meticulosa [...] na composição de cada imagem, na definição minuciosa dos detalhes" (CALVINO, 2005, p.75). Para criar um texto apoiado na montagem e na metonímia, é necessário ter amplo domínio da linguagem. A desorientação a que Oswald lança seu leitor é calculada, como a própria epígrafe aponta, e não fruto de "falhas" do autor.

\section{Conclusão}

Cremos que a análise das Memórias Sentimentais aqui entabulada ajuda a responder um dos questionamentos lançados no início de nosso trabalho. Vimos, por meio da obra oswaldiana, como os processos da memória, aliados à imaginação, podem ser recuperados e recriados na linguagem escrita. Miramar, recorrendo ao paradigma lançado pelas Memórias Póstumas de Brás Cubas, decompõe os elementos-padrão dos textos de memória ficcional e compõe-nos de uma maneira totalmente nova, subvertendo os esquemas prontos e fechados.

Alguns traços característicos do gênero memorialístico são mantidos, como a narração em primeira pessoa e o panorama da época (Miramar apresenta a São Paulo daquele período). Por outro lado, a cronologia esfacela-se, e o balanço de vida se torna quase que impraticável, pois o narrador não apresenta consciência crítica de seus atos. A gratuidade dos fatos selecionados para compor seu relato, sem que haja qualquer tipo de reflexão - a não ser a do último fragmento, no qual se opta por continuar a tradição da elite, de jactância e futilidade demonstram a inexistência de epifanias, autodescoberta, seleção de fatos significativos, reavaliação, redenção, etc. O que encontramos na obra de Miramar é completamente diverso do que se espera de um texto de memórias: uma compilação de fragmentos que "kodakam" fatos da mais completa frivolidade, expondo o meio fútil e de ostentação da elite paulista; são memórias vazias de um burguês vazio. Não há nada grandiloqüente, somente o discurso “institutal”; não há grandes feitos nem rememoração crítica.

Oswald, seguindo os passos de Machado de Assis, apropria-se dos elementos tradicionais da memória ficcional e transgride-os, não buscando uma mera destruição, mas tendo como objetivo propor uma renovação na cultura brasileira. Decompondo os paradigmas e recompondo-os por meio da fragmentação, montagem e construção metonímica, Miramar dialoga com a tradição brasileira e mostra que não são os modelos do passado que tolhem as inovações, e sim a intelectualidade ostentosa e tacanha, dominante nos inícios do século XX. Assim, nas Memórias Sentimentais fazer memória é, mais do que se debruçar sobre o passado, voltar-se para o futuro. 


\section{Referências}

ANDRADE, Oswald de. Memórias Sentimentais de João Miramar. São Paulo: Globo: Secretaria de Estado da Cultura, 1990a.

ANDRADE, Oswald de. Um homem sem profissão: sob as ordens de mamãe. São Paulo: Globo: Secretaria de Estado da Cultura, 1990b.

ASSIS, Joaquim Maria Machado de. Memórias póstumas de Brás Cubas. Porto Alegre: L\&PM, 1997.

BENJAMIN, Walter. O narrador: considerações sobre a obra de Nikolai Leskov. In: Magia e técnica, arte e política: obras escolhidas. São Paulo: Brasiliense, 1993. p.197221. Trad.: de Sérgio Paulo Rouanet.

BOSI, Alfredo. História concisa da literatura brasileira. São Paulo: Cultrix, 2004.

CALVINO, Italo. Seis propostas para o próximo milênio. São Paulo: Companhia das Letras, 2005. Trad.: de Ivo Barroso.

CAMPOS, Haroldo de. Estilística miramarina. In: e crítica literária. Petrópolis, RJ: Vozes, 1967. p.87-97. . Metalinguagem: ensaios de teoria - Miramar na mira. In: ANDRADE, Oswald. Memórias Sentimentais de João Miramar. São Paulo: Globo: Secretaria de Estado da Cultura, 1990. p.5-33.

CANDIDO, Antonio. Estouro e libertação. In: . Brigada ligeira e outros ensaios. São Paulo: UNESP, 1992. p.17-32.

FONSECA, Cristina (org.). O pensamento vivo de Oswald de Andrade. São Paulo: Martin Claret, 1987.

HELENA, Lucia. Totens e tabus da modernidade brasileira: símbolo e alegoria na obra de Oswald de Andrade. Rio de Janeiro: Tempo Brasileiro, 1985.

MARTINS, Wilson. A literatura brasileira: o modernismo. São Paulo: Cultrix: 1973.

PLATÃO. Fedro. In: . Diálogos. Porto Alegre: Globo, 1962. p.185-263. Trad.: de Jorge Paleikat.

SCHWARTZ, Jorge. Vanguarda e cosmopolitismo na década de 20: Oliverio Girondo e Oswald de Andrade. São Paulo: Perspectiva, 1983. 